\title{
Physiochemical Analysis of Some Saudi Arabia Honey
}

\author{
Ahmed G. Hegazi ${ }^{1 *}$, Faiz M. Al Guthami ${ }^{2}$ and Ahmed F.M. Al Gethami \\ ${ }^{1}$ National Research Centre, Dokki, Giza, Egypt \\ ${ }^{2}$ Al Guthami Foundation, Saudi Arabia \\ *Corresponding author
}

\begin{abstract}
A B S T R A C T
Keywords

Physiochemical analysis, Honey, Saudi Arabia

Article Info

Accepted:

15 January 2018

Available Online:

10 February 2018

Honey had been well documented as oldest traditional medicines. Its use is recorded in Egyptian papyri dated from 1900 to 1250 B.C. which used many of the Egyptian prescriptions including honey. It is also mentioned in the Holy Qu'ran. Honey enhancing the growth of tissues for wound repair, suppress inflammation, and bring about rapid autolytic debridement. The objective of this study was aimed to determine the Physiochemical analysis of some Saudi Arabia honey. The fresh 66 honey samples $(3 \mathrm{~kg}$ of each) were kindly provided by Alnahal aljwal Company, 2016 flowering season. Honey sample was collected in a sterile universal glass container and kept at $2-8^{\circ} \mathrm{C}$ until tested. Physiochemical analysis was done. Determination of sediment content, total grains, moisture content, water soluble solids, $\mathrm{pH}$, acidity, electrical conductivity, colour analysis, ash content, total protein content, sugars content, inverted sugars, glucose $(\mathrm{g} / 100 \mathrm{~g})$, fructose $(\mathrm{g} / 100 \mathrm{~g})$, fructose/ glucose sucrose $(\mathrm{g} / 100 \mathrm{~g})$ diastase enzyme activity, HMF and microbiological examination were performed. Physiochemical analysis of honey samples were varied according to different honey sources. It was obvious that the honey quality was varied based on the botanical origins.
\end{abstract}

\section{Introduction}

Bee honey (Apis mellifera) is the most wellknown and economically important for the production if different bee products which has a great importance in medical aspects. Honey is defined as the natural sweet substance produced by honey bees, which collected from the plant flowers nectars and honey dew (Codex Alimentations 2001). The geographical floral origin, season and environmental factors reflected on the honey properties and compositions (Da Costa Leite et al., 2000; Kas`konien_e et al., 2010; ElMetwally 2015 and El Sohaimy et al., 2015). Bee honey is one of the nutritive totally nonallergic foods and energetic provider Rahman et al., (2010), that body easily assimilates Bogdanov et al., (2004). The important factors related to honey quality are the sum of fructose, glucose, fructose/glucose ratio and glucose/water ratio which indicates the ability of honey to crystallize (White and Doner, 1980; Manikis and Thrasivoulou, 2001; Kas`konien_e et al., 2010 and Buba et al., 2013). The physicochemical properties of the 
honey depend on some elements as moisture content (El-Metwally, 2015 and El Sohaimy et al., 2015), melissopalynology (Stephens et al., 2010 and Ponnuchamy et al., 2014). Physicochemical parameters afford quantitative results and allow an approximate estimation of the presence of honey blends Soria et al., (2004). This study aimed to evaluate physicochemical characteristics of some Saudi Arabia honeys as well as to assess the different types of honey quality.

\section{Material and Methods}

\section{Honey}

A total of 66 samples of twenty-six Saudi honey types were analyzed. The samples were obtained 2017 flowering season directly from professional beekeepers who declared their botanical origin (From Authorized proved apiary farm of Alnahal aljwal, Saudi Arabia). Honey samples (1 $\mathrm{kg}$ each) were kindly provided by Alnahal aljwal Company. The collected honey samples were Shafalah (Capparis spinose), Tabyah [Acacia origena (A.negrii)], Fakhrah (Ziziphus nummularia), Dahianah (Acacia hamulosa - Acacia laeta), Wadi al Germ (Acacia hamulosa-Acacia laeta), Rawdat Khereem (Ziziphus nummularia). Wadi glianah [Capparis spinosa-Acacia origena (A.negrii)], Al Markh (Leptadenia pyrotechnica), Al begedi (Acacia asak- Acacia hamulosa), Gezan mountin (Ziziphus spina-Acacia asak-Anisotes trisulcus), Tanhat (Ziziphus nummularia), Wadi Al Adawa [Acacia origena (A.negrii)], Wadi Rock [Acacia origena (A.negrii)], Om Al Zaabah (Ziziphus nummularia), Om Al Asafeer (Ziziphus nummularia), Wadi Harmela [Acacia origena (A.negrii)], Horat Al Alaa [Capparis spinosa- Acacia origena (A. negrii)], Sidr (Ziziphus spina-christi), Sidr Al Ganoub (Ziziphus nummularia), Accacia (Acacia nilotica), Talh (Thymus vulgaris), Sidr Sheeh (Artemisia judaica), Korat
(Euphorbia cactus), Badiah Al Bahah [Ziziphus spina-christi and Artemisia Judaica], Wadi Al Faw [Acacia origena (A.negrii)] and Al Sahah (Acacia tortilisBlepharis ciliaris). Each honey sample was collected in a sterile universal glass container and kept at $2-8^{\circ} \mathrm{C}$ they were stored in the dark until tested.

\section{Physiochemical analysis of honey}

The physiochemical analysis of honey samples (El-Metwally 2015 and El Sohaimy et al., 2015). Determination of the pollen analysis using an Olympus BX41 microscope under 400 magnification. Pollen analyses of honeys were performed according to the methodology recommended by the International Commission of Bee Botany, and the International Honey Commission Louveaux et al., (1978) and total grains Maurizio (1975). To confirm the botanical origin of the honey samples, their general sensory characteristics.

Moisture content was determined from the refractive index of the honey (Bogdanov, 2009). Hydroxymethylfurfural was determined after clarifying samples with Carrez reagents (I and II) and addition of sodium bisulphite (based on methodology described in AOAC and Helrich (1990). Absorbance was determined at 284 and $336 \mathrm{~nm}$ in a $1 \mathrm{~cm}$ quartz cuvette in a Kontron spectrophotometer. Results were expressed as $\mathrm{mg} / \mathrm{kg}$.

Diastase activity was measured using a buffered solution of soluble starch and honey which was incubated in a specially designed glass tube, shaped to end in an inverted ' $\mathrm{V}$ ', in a thermostatic bath until the endpoint was determined photometrically (Spectronic 20). Results were expressed (as Gothe degrees) as $\mathrm{ml}$ of I\% starch hydrolysed by an enzyme in 1 $\mathrm{g}$ honey in $1 \mathrm{~h}$ (AOAC, 1990). $\mathrm{pH}$ was 
measured in a pH meter (AOAC, 2005) from a solution containing $10 \mathrm{~g}$ honey in $75 \mathrm{ml}$ of COz-free, distilled water. Sugar composition was performed as (AOAC, 2005). With all these analyses, the criteria laid down by the Regulations of the International Honey Commission (IHC 1997 and Saudi Arabia Regulations SASO (1990) were applied.

\section{Statistical analysis}

Data were analyzed statistically using student "T" test showing mean + SD. Data were compared using one way. Statistical significance was accepted at $\mathrm{p}<0.01$ according to ${ }^{41}$.

\section{Results and Discussion}

Total of 66 honey samples were collected belong 26 honey samples from different localities in Saudi Arabia. The results of the honey pollen analysis are shown in Table 1. The dominant pollen was illustrated. The moisture content of honey is highly important factor contributing to its stability against fermentation and granulation during storage (Singh and Bath, 1997). As well as to detect inappropriate storage conditions or possible adulteration during honey production (White, 1979; Kahraman et al., 2010; Kaskoniene et al., 2010 and da Silva et al., 2016). In this study, the moisture content of honey ranged from 11-18\% of samples (Fig. 1).

The results for the studied honey samples, showed moisture content below than $20 \%$ for the tested samples. Nevertheless, moisture content established by the European Union Directive e for heather honey is $23 \%$, which is considered acceptable for these samples. The EU Directive 2001/110/CE (EU, 2001) established a maximum value of $20 \%$ of water content, for honey intended for consumer use. They were in an acceptable range according to the regulations of the International Honey
Commission (IHC 1997 and Saudi Arabia Regulations SASO (1990).). The moisture content of samples in permitted levels was found similar to (Al-Khalifa and Al-Arify, 1999; Przybylowski and Wilczynska, 2001; Rodriguez et al., 2004; Nanda et al., 2003; Guler, 2005 and Duman et al., 2008). The different moisture content of honey depends on harvest season, the degree of maturity reached in the hive and moisture content of original plant (Finola et al., 2007).

These may be due to the climatic factors and storage conditions. On the other hand, moisture content of honey can vary as a function of the source of nectar used by the bees or the weather conditions of the region where the honey is produced.

The acidity of honey is due to the presence of organic acids, particularly the gluconic acid, in equilibrium with their lactones or esters and inorganic ions such as phosphate and chloride (Al-Khalifa and Al-Arify, 1999). The free acidity that is characterized by the presence of organic acids in equilibrium with their corresponding lactones and some inorganic ions, such as phosphate, sulfate and chloride, was lower than 50 mequiv. $/ \mathrm{kg}$ for the most studied honey samples (Soria et al., 2004; Kahraman et al., 2010; Kaskoniene et al., 2010 and da Silva et al., 2016). The mean value of total acidity was ranged from $6-90$ meq/kg (Fig. 2). Similar results were detected by Yilmaz and Kufrevioglu (2000) and Ozcan, et al., (2006). In Turkey and in Argentina a previous study, showed lower levels of total acidity were reported by by Yilmaz and Yavuz (1999) and Finola et al., (2007), respectively. Higher acidity was reported by Esti et al., (1997), Costa et al., (1999) and Cantarelli et al., (2008). Differences between the findings obtained from several studies and our findings may be caused to differences in geographical condition, harvesting procedure and storage condition. 


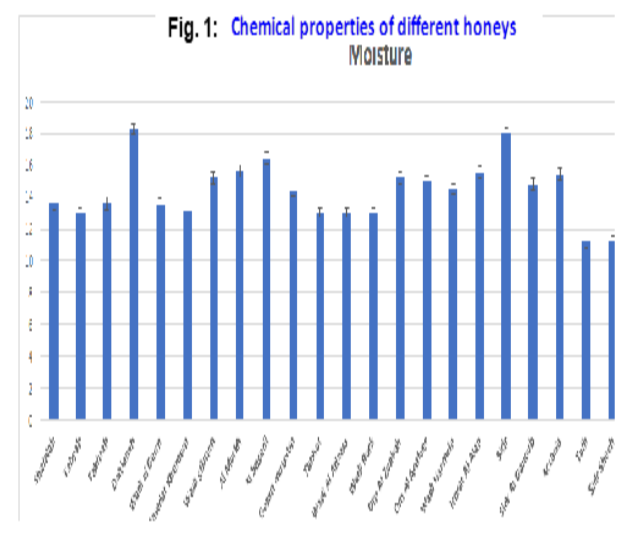

Fig.2: Chemical properties of different honeys Acidity

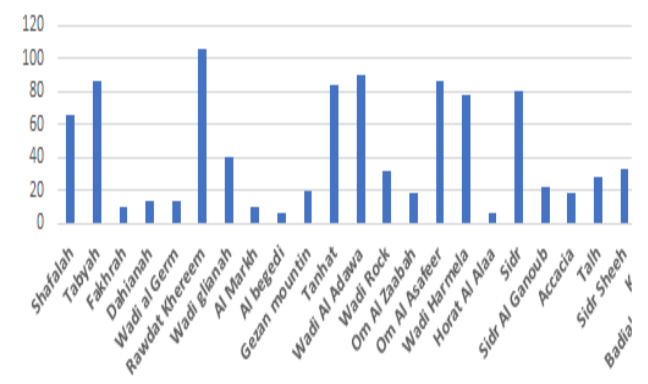

Fig. 3 Chemical properties of different honeys

Diastase enzyme

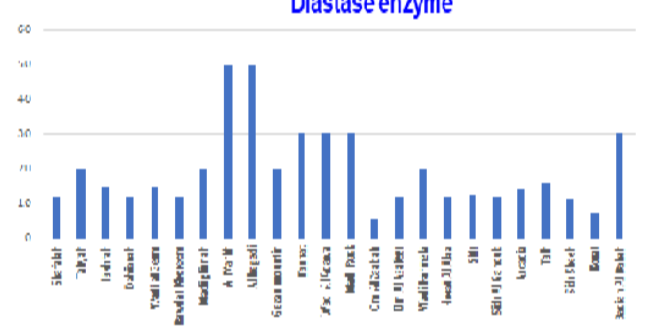

Fig. 4: Chemical proportizu of different homeys

HIM:

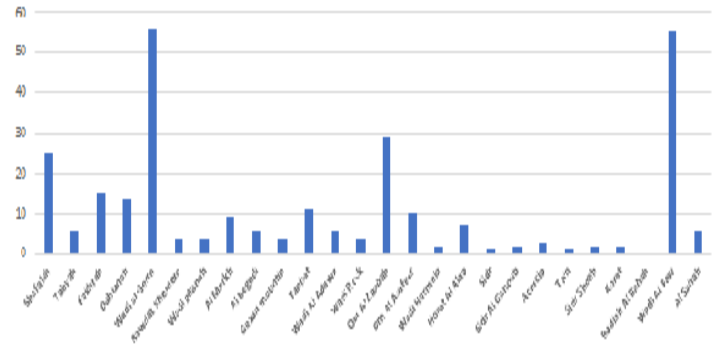

Fig. 5: Chemical properties of different honeys (Glucose \%)

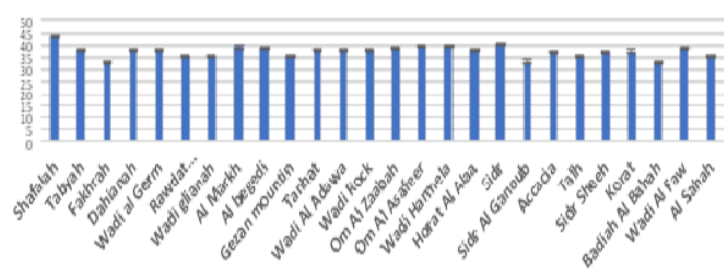

Fig. 6: Chemical properties of different honeys

(fructose \%)

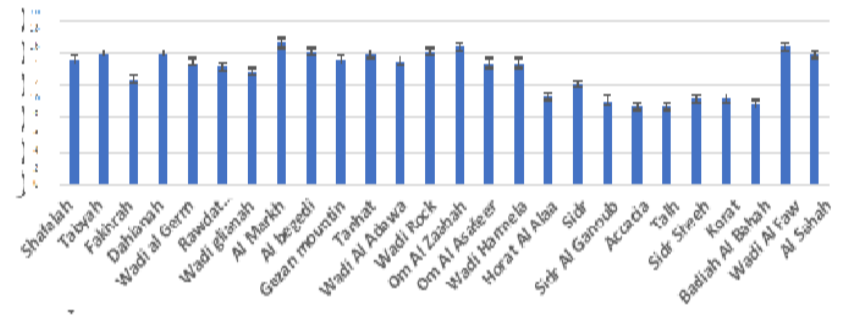

Fig.7: $F / G$ ratio

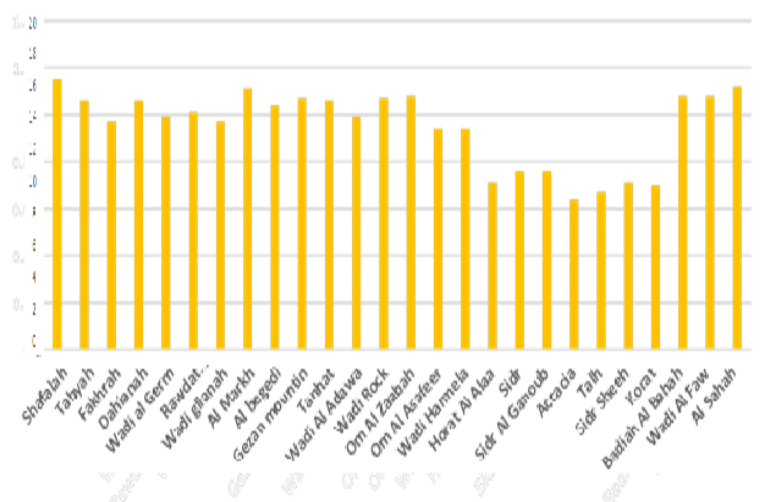

Fig. 8: Chemical properties of different honeys

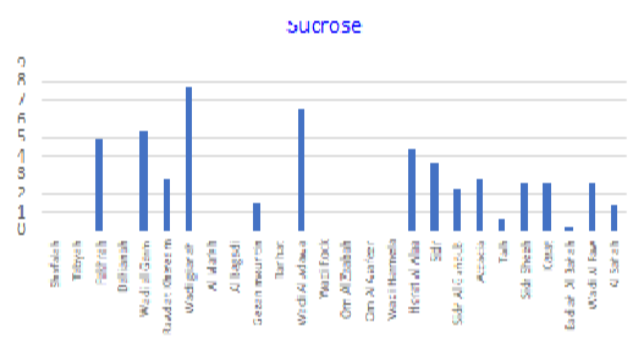


Table.1 Pollen in different honey samples

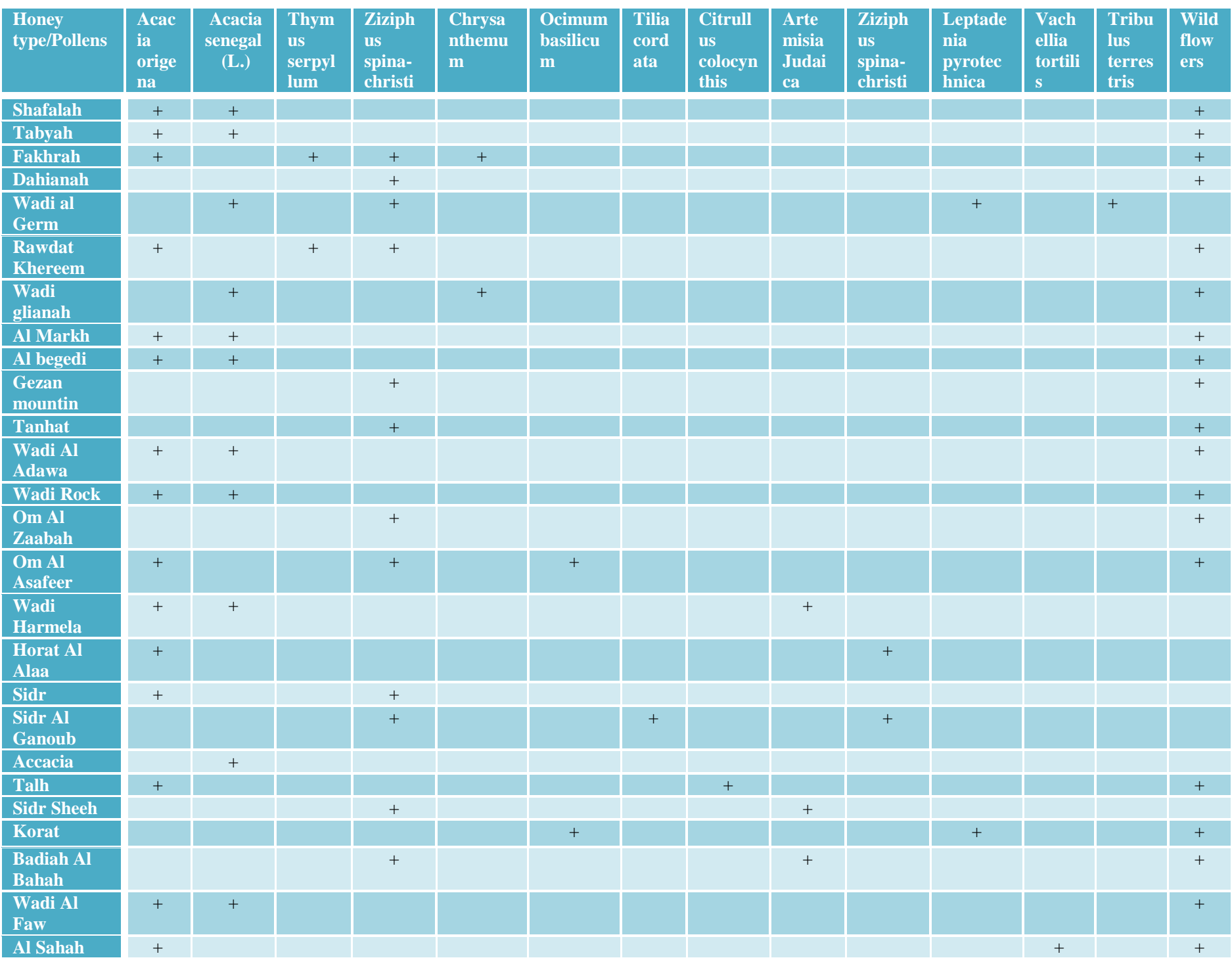

The widely recognized parameters indicating the freshness of honey are diastase activity and the HMF content (Mendes et al., 1998; Terrab et al., 2003). In the present study, diastase levels in honeys from different localities in Saudi Arabia were in the range of 6-50\% (Fig. 3). Devillers et al., 2004, Cantarelli et al., 2008, Sahinler and Gul 2004 and Esti et al., (1997) found that the diastase activity had a mean of $22.4 \%, 19.7 \%, 17.9 \%$ and $39.1 \%$, respectively. In contrary, lower values were found by Al-Khalifa and $\mathrm{Al}-$ Arify (1999) and Duman et al., (2008). The range of HMF was 1 to $55 \mathrm{mg} / \mathrm{kg}$ (Fig. 4). Significantly similar levels as data presented here were reported for honeys from France (3.28 mg/kg, Devillers et al., 2004), Italy (7.80 mg/kg, Esti et al., 1997), Spain (Nalda et al., 2005) and Turkey $(25.9 \mathrm{mg} / \mathrm{kg}$, Akyuz, et al., 1995). Mendes et al., (1998) reported $\mathrm{HMF}$ levels in the range of $1.7-471 \mathrm{mg} / \mathrm{kg}$. The variation in the activity of diastases and HMF may be related to source of honey as well as climate of region (Singh and Bath, 1997). 
The major constituents of honey are glucose, fructose and sucrose Figures 5-8. In this study, the levels of these sugars were ranged from 33-43 (glucose), 24 -43 (fructose) and 05.1 (sucrose). The $\mathrm{F} / \mathrm{G}$ ratio ranged from 0.7 to 1.2. Our findings showed approximately similarity with the results of Yilmaz and Yavuz (1999), Przybylowski and Wilczynska (2001), Erdogan et al., 2004 and Ouchemoukh et al., 2007. The level of sucrose differs according to the maturity degree and origin of the nectar compound of the honey. Cantarelli et al., (2008) reported sucrose content in honey samples at the average of $4.05 \%$. In another study, sucrose was detected between $2.21 \%$ and $5.52 \%$ (Rodriguez et al., 2004). Our findings showed approximately similarity with these results were detected in previous studies [Higher (Duman et al., 2008) and lower results (AlKhalifa and Al-Arify, 1999; Ozcan et al., 2006)]. The results of this study indicate that honeys contain sugar, bees were not fed with sugar solution instead of nectars, early harvesting before honey ripened in the honeycomb honeys have been mixed (Unal and Kuplulu, 2006).

From offer mentioned results concluded that the result of this study indicated that honey samples from different region of Saudi Arabia, were mostly at good quality. Honey samples that are available has differ in quality on account of various factors like seasons, packaging and processing conditions, floral source, geographical origin, and storage period.

\section{References}

Akyuz, N., Bakirci, I., Ayar, A., and Tuncturk, Y. (1995). Van piyasasinda satis_a sunulan balların bazı fiziksel ve kimyasal ozellikleri ve bunların ilgili standard uygunlug u uzerine bir aras_tırma. Gida, 20(5), 321326.

Al-Khalifa, A. S., and Al-Arify, I. A. (1999).
Physicochemical characteristics and pollen spectrum of some Saudi honeys. Food Chemistry, 67, 21-25.

AOAC and Helrich, K. (1990). (Eds.). Official methods of analysis (15th ed. Arlington, VA: Association of Official Analytical Chemists Inc. Methods 954.11-979.21 and 977.20, pp. 1028-1030.

AOAC, 1999. Association of Official Analytical Chemists, 16th ed. Official Methods of Analysis, Washington, DC.

AOAC, 2000. Association of official analytical chemists. Sugars and sugar products. In: Horwitz, W. (Ed.), Official Methods of Analysis of AOAC International, vol. 2(44), pp. 22-33.

AOAC, 2005. Association of Official Analytical Chemists. Official Methods of Analysis of AOAC International, 18th ed. Official Methods of Analysis, Maryland, USA.

Bogdanov, S., 2009. Physical properties of honey. In: Book of Honey, Chapter 4. Bee Product Science.

Bogdanov, S., Jurendic, T., Sieber, R., Gallmann, P., 2008. Honey for nutrition and health: a review. J. Am. Coll. Nutr. 27, 677-689.

Bogdanov, S., Lu“llmann, C., Martin, P., Von Der Ohe, W., Russmann, H., Mossel, B.L., D'Arcy, B., Vorwohl, G.R., Oddo, L., Sabatini, A.G., Marcazzan, G.L., Piro, R., Flamini, C., Morlot, M., Lheretier, J., Borneck, R., Marioleas, P., Tsigouri, A., Kerkvliet, J., Ortiz, A., Ivanov, T., Vit, P., Martin, P., 1999. Honey quality, methods of analysis and international regulatory standards: review of the work of the international honey commission. Bee World 80, 61-69.

Bogdanov, S., Rouff, K., Oddo, L.P., 2004. Physico-chemical methods for the characterization of unifloral honey: a review. Apidologie 35 (4), 275-282.

Buba, F., Gidado, A., Shugaba, A., 2013. Analysis of biochemical composition of honey samples from North-East Nigeria. Biochem. Anal. Biochem. 2 (3), 139. http:// dx. doi. org/ 10.4172/ 161- 1009.1000139.

Cantarelli, M.A., Pellerano, R.G., Marchevsky, E.J., Camin a, J.M., 2008. Quality of honey from Argentina: study of chemical composition and trace elements. J. 
Argentine Chem. Soc. 96 (1-2), 33-41.

Codex Alimentations, 2001. Draft revised standard for standard for honey (at step 10 of the Codex procedure). Alinorm 01 (25), 19-26.

Costa, L. S. M., Albuquerque, M. L. S., Trugob, L. C., Quinteiro, L. M. C., Barth, O. M., Ribeiro, M., et al., (1999). Determination of non-volatile compounds of different botanical origin Brazilian honeys. Food Chemistry, 65, 347-352.

Da Costa Leite, J.M., Trugo, L.C., Costa, L.S.M., Quinteiro, L.M.C., Barth, O.M., Dutra, V.M.L., 2000. Determination of oligosaccharides in Brazilian honeys of different botanical origin. Food Chem. 70, 93-98.

Da Silva P.M., Gauche C., Gonzaga LV., Costa A.C.O., FettR. (2016): Honey: Chemical composition, stability and authenticity. Food Chemistry 19. 309-323

Devillers, J., Morlot, M., Pham-Delegue, M. H., and Dore, J. C. (2004). Classification of monofloral honeys based on their quality control data. Food Chemistry, 86, 305-312.

Duman A. B., Sezer, C., and Oral, N. B. (2008). Kars'ta Satıs_a Sunulan Suzme Balların Kalite Niteliklerinin Aras_tırılması. Kafkas Universitesi Veteriner Fakultesi Dergisi, 14(1), 89-94.

El Sohaimy S.A., Masry S.H.D. and Shehata M.G. (2015). Physicochemical characteristics of honey from different origins. Annals of Agricultural Science 60(2), 279-287.

EL-Metwally, A.A.E., 2015. Factors Affecting the Physical and Chemical Characteristics of Egyptian Beehoney. Ph. D. Thesis, Fac. Agric. Cairo Univ., 320p.

Erdogan, Y., Dodologlu, A., and Zengin, $\mathrm{H}$. (2004). Farklı Cevre Kos_ullarının Bal Kalitesi Uzerine Etkileri. 4. Ulusal Zootekni Bilim Kongresi, 1-3 Eylul, Isparta.

Esti, M., Panfili, G., Marconi, E., and Trivisonno, M. C. (1997). Valorization of the honeys from the Molise region through physicochemical, organoleptic and nutritional assessment. Food Chemistry, 58(1-2), 125128.

European Union Directive (EU). (2002). European Union Directive 2001/110/EC relating to honey.

Finola, M. S., Lasagno, M. C., and Marioli, J. M. (2007). Microbiological and chemical characterization of honeys from central Argentina. Food Chemistry, 100, 16491653.

Guler, Z. (2005). Dog u Karadeniz Bolgesinde uretilen balların kimyasal ve duyusal nitelikleri. G1da, 30(6), 379-384.

IHC (Harmonized methods of the International Honey Commision) (1997). IHC responsible for the methods: Stefan Bogdanov. Liebefeld, CH-3003 Bern, Switzerland: Swiss Bee Research Centre FAM.

Kahraman T, KemaS B, Vural A., Sandık S A. (2010). Physico-chemical properties in honey from different regions of Turkey. Food Chemistry 123 (2010) 41-44

Kaskoniene, V., and Venskutonis, P. R. (2010). Floral markers in honey of various botanical and geographic origins: A review. Comprehensive Reviews in Food Science and Food Safety, 9, 620-634.

Louveaux, J., Maurizio, A., Vorwhol, G., 1978. Methods of melissopalynology. Bee World 59, 139-157.

Manikis, I., Thrasivoulou, A., 2001. Relation of physicochemical characteristics of honey and the crystallization sensitive parameters. Apiacta 36, 106-112.

Maurizio, A., 1975. Microscopy of honey. In: Crane, E. (Ed.), Honey: a Comprehensive Survey. Heinemann in cooperation with the Int. Bee Res. Ass, London, pp. 240-257.

Mendes, E., Brojo, P. E., Ferreira, I. M. P. L. V. O., and Ferreira, M. A. (1998). Quality evaluation of Portuguese honey. Carbohydrate Polymers, 37(3), 219-223.

Nalda, M. J. N., Yagu, J. L. B., Calva, J. C. D., and Gómez, M. T. M. (2005). Classifying honeys from the Soria Province of Spain via multivariate analysis. Analytical and Bioanalytical Chemistry, 382, 311-319.

Ouchemoukh, S., Louaileche, H., and Schweitzer, P. (2007). Physicochemical characteristics and pollen spectrum of some Algerian honeys. Food Control, 18, 52-58.

Ozcan, M., Arslan, D., and Ceylan, D. A. (2006). Effect of inverted saccharose on some properties of honey. Food Chemistry, 99, 
$24-29$.

Ponnuchamy, R., Bonhomme, V., Prasad, S., Das, L., Patel, P., 2014. Honey pollen: using melissopalynology to understand foraging preferences of bees in tropical South India. PLoS ONE 9 (7), 1-11

Przybylowski, P., and Wilczynska, A. (2001). Honey as an environmental marker. Food Chemistry, 74, 289-291.

Rahman, M.M., Allan, R., Azirun, M.S., 2010. Antibacterial activity of propolis and honey against Staphylococcus aureus and Escherichia Coli. Afr. J. Microbiol. Res. 4, 1872-1878.

Rodriguez, G. O., Ferrer, B. S., Ferrer, A., and Rodriguez, B. (2004). Characterization of honey produced in Venezuela. Food Chemistry, 84, 499-502

Sahinler, N., and Gul, A. (2004). Yayla ve ayciceg i ballarının biyokimyasal analizi. 4 . Ulusal Zootekni Bilim Kongresi, 1-3 Eylul, Isparta.

Saudi Arabian Standards Organization, SASO (1990). Saudi Arabian standards, test methods of honey No. 102. Saudi Arabia: Ministry of Commerce.

Singh, N., and Bath, P. K. (1997). Quality evaluation of different types of Indian honey. Food Chemistry, 58(1-2), 129-133

Soria, A.C., Gonzalez, M., Lorenzo, C., Martinez, C.I., Sanz, J., 2004. Characterization of artisanal honeys from Madrid (Central Spain) on the basis of their melissopalynological, physicochemical and volatile composition data. J. Food Chem. $85,121-130$.
Stephens, J. M., Schlothauer, R. C., Morris, B. D., Yang, D., Fearnley, L., Greenwood, D. R., et al., (2010). Phenolic compounds and methylglyoxal in some New Zealand Manuka and Kanuka honeys. Food Chemistry, 120, 78-86.

Terrab, A., Diez, M.J., Heredia, F.J., 2003. Palynological, physicochemical and colour characterization of Moroccan honeys: I. River red gum (Eucalyptus camaldulensis Dehnh) honey. Int. J. Food Sci.Technol. 38, 379-386

Unal, C., and Kuplulu, O. (2006). Chemical quality of strained honey consumed in Ankara. Ankara Universitesi Veteriner Fakultesi Dergisi, 53, 1-4.

White JW Spectrophotometric Method for Hydroxymethylfurfural in Honey. J.Ass. Off. Anal. Chem. 1979; 62: 509.

White, J.W., Doner, L.W., 1980. Honey Composition and Properties: Beekeeping in the United States. Agriculture Handbook No. 335, pp. 82-91.

Yilmaz, H., and Kufrevioglu, I. (2000). Composition of honeys collected from eastern and south-eastern Anatolia and effect of storage on hydroxymethylfurfural content and diastase activity. Turkish Journal of Agriculture and Forestry, 25, 347-349.

Yilmaz, H., and Yavuz, O. (1999). Content of some traces metals in honey from southeastern Anatolia. Food Chemistry, 65, 475-476.

\section{How to cite this article:}

Ahmed G. Hegazi, Faiz M. Al Guthami and Ahmed F.M. Al Gethami. 2018. Physiochemical Analysis of Some Saudi Arabia Honey. Int.J.Curr.Microbiol.App.Sci. 7(02): 1441-1448. doi: https://doi.org/10.20546/ijcmas.2018.702.174 